\title{
Blended Learning Model of College English Supported by Social Media
}

\author{
Xianjun Tan \\ School of Foreign Languages\&International Office \\ Sichuan University of Science and Engineering \\ Zigong, China 643000 \\ Email: 64709511 [AT] qq.com
}

\begin{abstract}
In mainland China, the focus of college English learning should be on the application ability of students.The integration of English learning and social practice not only equips students with adequate knowledge, but also good application of English language and improved comprehensive quality.The use of social media in college English learning provides a new learning model.Various English teaching and learning activities could be conducted with the help of social media. In this way,students integrate the self English learning with the social practice, which improves the quality of English learning and caters for the needs of the society.
\end{abstract}

Keywords--- Social media; College English; Blended learning model

With the progress of the network platform, the concept of blended learning model becomes popular in English learning.This model integrates traditional learning methods with online learning,classroom with Internet, which brings the strength of the students into full play and realizes good learning effect.The popularization and development of Internet technology facilitates the English learning.Students not only learn English in the classroom, but also integrate the classroom learning with after school study. Hence, it improves the timeliness of English learning and makes the English learning more flexible and more practical.At the present time, English learning with the help of Internet technology has made great progress. English learning supported by social media would facilitate the application of English language and improve the overall English learning efficiency as well.

\section{SOCIAL MEDIA AND BLENDED LEARNING MODEL}

\subsection{Social Media}

Social software mainly refers to the software patterns based on information technology and Internet technology. People don't have to communicate face to face, but exchange and communicate in the means of words, video and voice via social media. The frequently used social soft ware includes QQ,Wechat, E-mail,SNS,etc. These software focus more on the information exchange and share between people and people. Learning supported by these software helps the students participate in the learning process and improve their learning ability in the practice. It integrates different social values into teaching and learning, which helps the students to realize the unity of learning and society and improve the quality of English learning .

\subsection{Blended Learning Model}

Blended teaching and learning mainly refers to that classroom teaching and learning is not the only method in the teaching and learning process any more, in-class teaching activities and extracurricular teaching activities would be combined, the Internet model and the real model would be combined, the Internet teaching model and the real practice would be combined. In terms of blended learning model of College English, the method used by teachers and students needs to be changed, full respect would be given to the autonomous learning ability of students to improve their learning efficiency.Blended learning model would integrate teaching resources and students resources. Teachers would use different teaching methods to cultivate the students, guiding students to pay attention to the the transmission of media and information, reap more in English learning with less cost.Blended learning model integrates the real teaching practice and the autonomous online learning, in which, the students would access more resources via social networking websites and engage in real English using environment. Students would realize their weaknesses in their own college English learning and change their learning strategy accordingly and timely, in this way, they would improve their learning efficiency and cater for the needs of the social development. 


\section{PRACTICABILITY OF THE MODEL}

\subsection{Requirements of the Teaching Objective}

College English Curriculum Requirements has been drawn up by China's Ministry of Education to provide colleges and universities with the guidelines for English instruction to non-English major students. The requirements clarify the teaching plan of college English,stipulate taking advantage of modern information technology, innovating the traditional teaching methods, enriching modern teaching techniques, providing more adequate resources and environment for the learning of students, motivating students' activity and initiative. In junior and senior middle school, students pay much attention to the scores in the English examination, however, the teaching objective of college English should focus on the real application ability and language expression ability of the students. Students should combine the real environment with the language application ability.

\subsection{Needs of the Development of Internet Technology}

In recent years, Internet technology has made great progress and become popular among students. Students establish their own English learning platform online. They could contact some English learning websites and organize the exchange with foreign students,in which,they could use English to communicate and cooperate with each other. Students grasp more practical experience in using English and they don't have to spend more time on the English application after their graduation,because they would have improved their English language learning ability and application ability during the online exchange.

\subsection{Needs of the Society}

With the development of economy, globalization has been brought into focus.Globalization is primarily an economic process of integration that has social and cultural aspects, which would generate further interdependence of economic and cultural activities. English as the most widely used language in the world, its significance for the college students is obvious and undisputed. Hence, students should pay much attention to the cultivation of English ability, especially the application ability,that is ,how to use English in real situation. Real situation is an important component in English learning.Learning English in a real situation improves the learning efficiency and accuracy. In real situation, students will speak English spontaneously, improving their English sense and and English learning ability imperceptibly. Social media could provide special situation for students to practice.

\subsection{Inherent Requirements of English Learning}

English learning has its own characteristics. Students need to read a lot and speak a lot to put what they learn into practice and cultivate their language ability. However, in the traditional teaching environment, English majors in the universities and colleges practice English a lot, non-English majors only practice listening, speaking, reading and writing in English class, they seldom practice English in other situations. Hence, English learning of many students can not meet the needs of the practice(Min Huang,2016). In respond to this, social media as a platform meets the needs of the students. Students can find some special context to learn English, take active part in oral English competition or exchange organized by some English associations, spend the extracurricular time to learn English. With the aid of social media, teachers can organize some English exchange activities to provide better situation for students' English learning, which motivate the students' enthusiasm for English learning and bring students' English application ability into full play.

\section{CLASSROOM TEACHING}

\subsection{Class Preview}

In terms of using social media technology, it is necessary to redraw the teaching plan in the teaching process. Online supporting teaching materials should be used actively to arrange the corresponding courses. Combing a large number of open teaching materials with online exercise test should be realized. Online classroom exercise should be combined with the students' own learning. The consistency of students' classroom learning and after class learning should be cultivated. Necessary support should be provided for the students' future learning.In terms of English teaching supported by social media, teachers can provide necessary support for students in the process preview, solve the problems of students online, let the student know more about the content they need to learn and have a clear target, provide necessary support for the cultivation of the students' ability.For example, when learning the book New Horizon College English,teachers could establish corresponding online platform. Via the platform, students can conduct online course learning and test, and prepare for the later learning according to the test result. Teachers should not intervene too much in students' learning process. Students' autonomy in the process are fully respected and they can make up their own learning plan according to the test result.

\subsection{Classroom Learning}

Teachers can adjust their teaching according to the feedback of the students in class preview, encourage the students to give their advice and create an active classroom atmosphere. In classroom teaching, teachers could use social media to 
create real English language environment for students and let them feel the real language environment. Interactive teaching method could be applied in the classroom teaching. The initiative in class learning belongs to students and they could promote their interest in English learning through active learning. Teachers can integrate students with different English levels with the aid of social media, then, students can learn from each other and make progress through mutual learning.

\subsection{After-class Discussion}

Through online autonomous learning and classroom learning, Students have mastered the basics of the course, but they lack the corresponding learning environment to consolidate what they have learned and discuss the existing problems. In respond to this, after-class learning platform could be established via social media, in which, students can express their opinions actively, probe into the problem autonomously, discuss and analyze the problem with others. If they can't solve the problem, they can seek help from the teacher. In this way,students can enhance their mastery of the course effectively(Yunfei Xu,Hongjun Wei,2016).For example, if there are international students learning in their university, teachers could gather the international students with Chinese students together and establish corresponding social network platform. Interesting activities could be organized to create more authentic language environment for the students. In this way, students can get to know how to use English more reasonably, improving and perfecting their oral English and listening ability. Gradually, students would be willing to learn English and have more self-confidence in English learning.

\section{APPLICATION OF THE MODEL}

\subsection{Application in College English Writing}

Writing is a key part in English learning and is an important part in College English Test Band 4 and 6 in mainland China as well. Generally, there are several steps for students to write in English:first draft, revision,final version and teachers' correction. In traditional teaching and learning model, it takes a long time for the students to write, during which, there is lack of sound communication between teachers and students. It is difficult for students to get feedback if they have problems, which causes the teaching of English writing is not so efficient on the whole.With the support of social media,the writing process could be shortened. The part that teachers correct students' writing in traditional teaching environment could be improved. Teachers could correct students' writing online and overcome the limitation of writing in a piece of paper, improving the teaching quality. Social media provides a good writing model for students. Compared to the sentences in the books or news report, people are better at remembering the postings in the Facebook or the casual words in the online forum(Wenming Li, Fuyu Lyu,2013). One possible reason is that the spontaneous words in one man's mind,which are relatively unfiltered, are ready-made words that are easily stored in another man's mind, which may explain why Twitter, Facebook and reality TV show are successful.Students may learn a lot via social media to help them write in English.

\subsection{Application in Oral English}

Oral English is difficult for many college students in mainland China. Lack of sound language environment for English learning makes some students reject the oral English practice and makes the students feel difficult in English learning. Learning model supported by social media provides a good model for students. Students could find some association activities concerning oral English via social media, participate in the real situation, join the various practical activities of the associations. Through immersing themselves in the authentic context, students could find out their own weaknesses and try to correct them and improve their own oral English ability. As outstanding English majors, teachers may have contact with some foreign teachers or students, they could integrate the resources, introduce excellent English teaching and learning resources into the real teaching, make the students fully experience the importance of oral English in daily learning. Teachers should guide students to solve some real problems with oral English and improve their oral English ability at the same time.

\subsection{Application in College English Reading}

In terms of college English learning, reading undoubtedly plays an important role.With good reading ability, students can pass the English examination and find useful resources. In traditional teaching, the cultivation of English reading ability is somewhat rigid, in which ,students learn the materials in the text books. The content of the text books may not be so close to the reality, which makes the cultivation of reading ability is not so effective. The teaching model supported by social media can integrate the latest findings in the society with English reading and make students keep up with the trend of the times.English is a living and constantly changing language,students need to learn the new words in order to have a better understanding of the English materials. In college English test of mainland China,reading comprehension part involves materials on current events. Learning the latest materials via online media could improve students' efficiency in English reading. Some expressions in the latest materials may be not common in the text books, but they often occur in the reading comprehension part in the college English test. Students should be trained to read via social media in order to obtain more abundant reading materials. 


\section{CONCLUSION}

Blended learning model of college English supported by social media is very interactive. Through a series of interaction between teachers and students, sound communication among students, students strengthen their autonomous English learning ability. Students integrate the English learning with social practice and establish their own good college social media. They not only learn the basics of English, but also cultivate various language skills, especially oral English skills and English reading skills. The blended learning model increases the interaction between teachers and students, combines the English learning with students' social circle, which makes the students experience the real language environment and learn English naturally in daily life.

\section{REFERENCES}

[1]Min Huang, Construction and Application of Blended Learning Platform Based on Wechat,Yangtze River Series,2016 (9) :52-53

[2]Wenming Li, Fuyu Lyu, Innovative Development and Industrialization of Online Learning,Proceedings of the 2013International Forum on Higher Education,2013:16

[3]Yunfei Xu,Hongjun Wei,The Research Situation Analysis of Mobile-assisted English Learning in 2015 in China.Journal of Bingtuan Education Institute,2016:58-62 